J. Lake Sci. (湖泊科学), 2013, 25(1): 1-8

http: //www.jlakes.org. E-mail : jlakes@niglas.ac.cn

(C) 2013 by Journal of Lake Sciences

\title{
湿地种子库及其植被恢复研究进展"
}

崔娜欣, 吴 娟, 成水平**, 周 琪

(同济大学长江水环境教育部重点实验室,上海 200092)

摘 要: 近年来,受损湿地生态系统的植被恢复与重建掀起了湿地植被恢复的热潮. 种子库是过去植物的 “记忆库”, 是湿 地植被自然恢复的重要潜力. 本文从湿地种子库的形成、湿地种子库的规模及空间分布格局、湿地种子库的物种组成及 种子库与地表植被的关系等几个方面总结了湿地种子库主要研究内容的国内外研究进展, 并重点介绍了湿地种子库在 湿地植被恢复中的应用研究, 尤其是湿地种子库幼苗萌发主要影响因素、湿地种子库种苗建群适宜生境及湿地种子库植 被恢复潜力等内容的研究现状. 在此基础上, 对目前湿地种子库及植被恢复研究存在的问题以及将来可能的研究方向进 行分析, 以期对湿地种子库植被恢复理论及实践技术的发展提供参考.

关键词: 湿地;种子库;植被恢复;进展及展望

\section{Research progress of seed bank for restoration of wetland vegetation}

\section{CUI Naxin, WU Juan, CHENG Shuiping \& ZHOU Qi}

( Key Laboratory of Yangtze Water Environment, Ministry of Education, Tongji University, Shanghai 200092, P. R. China)

\begin{abstract}
Recently, restoration and reclamation of vegetation in degraded wetland ecosystem have become a hot subject. As a reservoir of past plants, seed bank has huge potential for natural re-generation of wetland vegetation. In this review, we provided an overview of the major researches and progresses in the wetland seed bank formation, size and spatial pattern, species composition and relationships between seed bank and standing vegetation at home and abroad. Some case studies of wetland restoration using soil seed bank are introduced here, especially focused on main factors affecting seedling emergence of soil seed bank, safe sites for establishment of seedling and restoration potential of soil seed bank. We further discussed the main problems presented in the wetland re-vegetation from soil seed bank at present research and its possible direction of future studies. This review is expected to be a key reference for the development in the theory and practical techniques of restoration of wetland vegetations from soil seed bank. Keywords: Wetland; seed bank; re-vegetation; progress and prospect
\end{abstract}

近几十年来,随着工农业的迅猛发展、人口的大量增加和城市化进程的不断加快,湿地正面临着区域生 态环境破坏、自然景观消失、生物多样性减少、生态系统功能丧失等多种生态灾难. 因此, 恢复和重建湿地生 态系统结构、创造良好湿地生态系统以维持水体生态功能具有其重要性和必要性. 作为湿地生态系统的三 大基本要素之一, 湿地植物的恢复对于湿地的保护和生态恢复具有至关重要的意义. 自 1990s 以来,随着全 球范围的生物多样性保护意识的增强,有越来越多的基金资助濒危湿地物种的保护与恢复, 同时国际上有 关受损湿地植被恢复与重建的研究大量涌现, 掀起了湿地植被恢复研究的热潮 ${ }^{[1]}$.

种子库是过去植物的 “记忆库”, 是植被自然恢复的重要潜力, 对退化生态系统植物群落的快速恢复至 关重要 ${ }^{[2]}$. 同时也正是这些种子使群落和生态系统在遭受干扰或破坏后能够补充新个体和完成演替, 在一 定程度上可以预期未来的植被结构和演替动态 ${ }^{[3]}$. 湿地种子库的研究已经有 150 多年的历史, 最早可以追 溯到 19 世纪中期达尔文采集池塘淤泥进行种子萌发的实验 ${ }^{[4]}$. 1970s 未期, 以 Van der Valk 和 Davis 的一系 列研究为起点 ${ }^{[5-6]}$, 湿地种子库研究在北美和欧洲广泛展开, 并逐渐深人到植物生态学、恢复生态学、环境科

* 国家水体污染控制与治理科技重大专项项目 (2011ZX07303-001) 资助. 2012-02-14 收稿;2012-06-18 收修改 稿. 崔娜欣,女,1979 年生,博士研究生,工程师;E-mail : wmissu@ sohu. com.

** 通信作者;E-mail:shpcheng@yahoo.com.cn. 
学、进化生物学、工程学等诸多学科, 涉及植物群落和物种的保护、管理和恢复以及预测有关环境变化所导 致的植被潜在变化等领域. 近期, 许多学者开始重点研究种子库在湿地植被恢复中的作用,有活力的种子库 被认为是湿地植被建群和恢复的关键因素 ${ }^{[7-9]}$. 在我国持续加大对天然湿地保护和退化湿地恢复投入的大 背景下, 国内学者在近十年逐渐开展了一些湿地土壤种子库的研究, 其中大部分工作针对的是长江中下游 富营养化浅水湖泊 ${ }^{[10-13]}$.

种子库对于成功恢复植被群落具有重要的指示作用 ${ }^{[7,14-15]}$. 首先, 通过研究种子库的组成可以确定受损 湿地的物种资源储备和评判它的自我恢复能力, 同时为植被恢复提供管理策略. 其次, 许多湿地植物具有长 期续存的种子库, 累积在底泥中的种子承受的干扰较小, 因而与地表植物相比种子库对各种外界干扰具有 更大的忍耐性. 此外, 种子库可能累积更多的在不同选择压力下产生的基因, 因此在濒危物种保护和湿地植 被恢复中具有不可取代的作用 ${ }^{[15]}$. 2011 年 8 月在墨西哥尤卡坦半岛召开的生态恢复学会国际会议 (SER2011) 认为在人类过度干扰和全球气候变化加剧的双重胁迫的背景下, 生态恢复有可能是人类应对气 候变化不利影响、栖息地丧失、物种灭绝的最重要的工具之一. 在大会的特别专题中即包括了种子库恢复的 专题. 目前, 土壤种子库的研究已成为国际恢复生态学研究的热点和前沿 ${ }^{[16]}$.

\section{1 湿地种子库}

\section{1 湿地种子库的形成}

广义的种子库是指基质 (或土壤) 表面或基质中具有繁殖能力的种子、果实、无性繁殖体以及其它能再 生的植物结构的总称 ${ }^{[17]}$. 狭义的种子库是指存留于基质 (土壤) 表面及基质中有活力的植物种子的总和 ${ }^{[2]}$. 种子库中的种子来源于种子雨, 种子成熟撒落后一部分被保留在基质 (土壤) 表面或枯枝落叶中, 但大部分 会因为各种生物或非生物因素进人土壤并被埋藏其中 ${ }^{[18]}$. 大多数种子散落到地表或进人土壤后, 要经历休 眠阶段, 由于物种种类和环境条件的差异, 休眠时间可以从几天到很多年, 因此植被都具有或大或小的种 子库.

一些生物因素如动物行为和人类活动等在一定程度上影响着湿地种子库的形成. 有研究表明人类的耕 作是影响湿地种子库密度和组分变化的主要因素之一 ${ }^{[4]}$. 很多非生物因素也为种子库的形成创造了条件, 其中水传播是植物繁殖体的重要次生散布方式之一 ${ }^{[19]}$. 相比种子从母体脱落直接传播的初始散布, 水传播 能实现较长距离的繁殖体散布 ${ }^{[20]}$. 水传播散布的种子数目极大, 沉积到河流水体中即可形成种子库, 为河流 湿地的植被恢复提供物种基础 ${ }^{[21]}$. 湿地因水位变化沉积下来的沉积物中具有大量的种子, 且部分种子能萌 发出新个体 ${ }^{[8,22]}$. 湿地季节性干裂为种子进人底泥开辟了途径, 导致种子的深埋, 为在底泥深处构建一个有 生命力的种子库提供了有力保障 ${ }^{[23]}$.

\section{2 湿地种子库的规模及空间分布格局}

1.2.1 湿地种子库的规模 通常所指的土壤种子库的规模 (大小) 是单位面积土壤中有活力的种子的数量, 即种子密度. 种子库的大小是深人开展湿地种子库研究的基础. 研究发现不同类型的湿地生境中种子库的 大小差异很大, 从湖泊消涨带、河流、溪流、冲积平原到河岸带、河滨沼泽等不同生境中的种子库规模在 $80 \sim$ 30000 粒 $/ \mathrm{m}^{2[3]}$. 刘贵华等的研究表明在亚热带浅水山地沼泽中种子库的密度是 $7188 \sim 11211$ 粒 $/ \mathrm{m}^{2}$, 在湖滨 沼泽中的密度为 $10205 \sim 141161$ 粒 $/ \mathrm{m}^{2[12,24]}$. Yuan 等研究了亚热带湖滨沼泽沿水位梯度变化种子库的物种 分布格局, 结果表明沉水植物带的种子库中以沉水植物和浮叶植物为主, 而挺水植物带的种子库物种以挺 水植物为主 ${ }^{[25]}$. 大量研究也表明种子库含有比地表植被更多的物种, 甚至一些已经灭绝的物种在种子库中 出现 ${ }^{[15]}$. Nishihiro 等对日本 Kasumigaura 湖种子库的物种调查中共发现 180 个物种, 其中包括 12 种已经消 失的乡土沉水植物, 表明湿地种子库巨大的物种恢复潜力 ${ }^{[8]}$.

1.2 .2 湿地种子库的空间分布格局及其主要影响因子 种子在土壤中的分布格局与地表植被、生境类型和 气候条件密切相关, 并主要由种子寿命、种子休眠机制和扩散过程决定 ${ }^{[26]}$. 土壤种子库中种子的分布分为垂 直分布和水平分布, 其中垂直分布主要影响种群建群, 水平分布则在一定程度上决定种群的格局 ${ }^{[4]}$.

许多湿地植物具有长寿的种子, 因此每年产生的种子随着底泥的不断沉积形成明显的垂直分布 ${ }^{[23,27]}$. 有研究表明种子库在湖滨底泥中的垂直分布能够部分反映植被历史 ${ }^{[13]}$. 对各类湿地种子库的研究表明单位 
面积种子数随着土壤深度的递增而减少, 种子主要集中分布于表层 $4 \mathrm{~cm}$ 的土壤中, 当深度增加到 $8 \sim 12 \mathrm{~cm}$ 时种子密度甚至减少到零 ${ }^{[28]}$.

湿地种子库的水平分布格局往往与地表植被、种子扩散、环境水位梯度、洪涝或干旱导致的水位剧烈变 化等特定的生境条件以及生境的异质性有关 ${ }^{[3,29]}$. Nilsson 等对河岸种子库沉积机制的研究发现在河流中的 漩浴及缓流区的外弯道处等往往沉积较多的种子 ${ }^{[30]}$. Jutila 的研究表明, 在湿地不同生境条件下种子的分布 密度很不均匀, 在某些湿地植被丛下能聚集种子, 其单位面积的种子数要比开阔地高 ${ }^{[31]}$. 刘贵华等发现在淡 水湿地种子库的小尺度空间格局中地表植被优势种的种子呈聚集分布 ${ }^{[32]}$. Cockel 等对英国 Brent 河种子库 分布格局的研究表明靠近河岸边的种子库物种相对更丰富 ${ }^{[33]}$. 大量的研究表明种子库的空间分布格局主要 与地表植被相关, 并受水文因素变化的影响, 生境条件的异质性决定了种子库在小尺度空间格局的分布状 态. 通过对湿地种子库水平分布格局、种子传播机制及其与环境因子关系的研究, 可以了解湿地种子传播及 沉积的主要影响因素及其影响机制,进而为湿地恢复工程设计及管理措施的制定提供理论依据.

\section{3 湿地种子库的物种组成及其主要影响因素}

湿地种子库物种组成是湿地种子库研究的重点内容之一. 已有研究表明湿地种子库的物种组成主要受 地表植被或群落组成的影响, 不同群落的种子库组成具有很高的变异性, 另外群落所处的演替阶段、动物捕 食、水文、干旱等各种因素也对种子库的物种组成产生影响 ${ }^{[3,24]}$. 湿地种子库的动态受种子输人和种子丧失 过程的影响, 水文变化如洪水和水位波动在这个过程中都发挥着重要作用 ${ }^{[34-35]}$. 水文变化不仅影响种子萌 发, 同时它也能传播种子, 为湿地种子库带入新个体 ${ }^{[36]}$. 在对沙漠洪泛平原的研究发现, 洪水高频区比低频 区的湿地种子库物种丰富度高, 物种组成复杂, 表明洪水频率直接影响着种子库的大小和组成 ${ }^{[37]}$. 另外, 湿 地种子库物种组成的研究方法不同对研究结果也会产生一定的影响, 处理方式的不同对种子萌发的影响也 不同, 从而在一定程度上影响研究区域的物种组成 ${ }^{[4,38-39]}$. 李守淳等研究蚌湖湖滨带种子库特征时发现湿润 条件下种子库萌发的物种以湿生和挺水植物为主, 而在淹水条件下萌发的沉水植物种类和幼苗数量显著增 多 ${ }^{[39]}$. 由此可见, 除种子库自身的特点外, 采样时间尤其是研究方法等因素也会影响种子库的物种组成, 在 湿地种子库植被恢复研究中往往以实际研究目的来确定种子库的研究策略. 湿地种子库的物种组成是利用 种子库进行湿地植被恢复的物质基础, 它决定了利用种子库进行植被恢复的潜力以及恢复后的湿地植被组 成和未来演替方向, 是湿地种子库植被恢复研究的基础内容.

\section{4 湿地种子库与地表植被的关系}

土壤种子库是地上植被更新的重要种源, 种子库与地表植被物种组成的关系是种子库研究的主要内容 之一. 土壤种子库在植物群落演替中具有重要作用: 一方面, 土壤种子库是植物群落演替的驱动因子之一; 另一方面, 土壤种子库又是植物群落的产物. Van der Valk 于 1981 年提出的植被演替模型通过整合相关的 物种生物学特征、种子库物种组成以及种子萌发和幼苗成活的适宜环境条件等方面的知识, 解释了种子库 如何决定地表植被的演替 ${ }^{[40]}$. 许多研究已经表明,湿地植物具有长期续存的种子库,种子库中的种子可以在 不同的环境条件下萌发, 补充到地表植被中, 进而影响地表植被的组成和结构, 在干扰严重和频繁的区域, 种子库对地表植被的影响尤其显著 ${ }^{[41]}$. 几乎所有研究都显示, 种子库中含有比地表植被中更多的物种. 然而 由于环境干扰、不同物种种子库的萌发条件以及物种的繁殖策略等因素的影响,一些研究结果显示种子库 基本上反映了地表植被的组成 ${ }^{[6,25]}$; 一些研究则表明种子库与地表植被的物种组成差异很大 ${ }^{[39,41-42]}$. 刘贵华 等认为地表植被的组成和结构更容易受环境变化的影响,同一位点的地表植被在不同环境条件和不同季节 时会出现很大的差异, 相对而言, 种子库的物种组成更加稳定 ${ }^{[15]}$. 刘贵华等对长江中游季节性枯水的湖滨沼 泽湿地地表植物和种子库的研究发现, 在枯水期地表植被以沼生和挺水植物为主,在雨季地表植物以沉水、 浮叶和高大挺水植物为优势种, 而种子库则决定了两个时期的植被类型, 在湖滨沼泽地表植被演替中具有 十分重要的潜在作用, 根据研究数据可以利用 Van der Valk 的演替模型很好地预测该区域的植被周期性变 化 ${ }^{[12]}$. 种子库与地表植被的组成会因不同时期水文条件的变化而异,但二者的相似性关系具有不确定性,一 些不可预见的干扰也会影响其相似性,对于其干扰机制有待于进一步研究.

我国在湿地种子库与地表植被关系方面的研究工作部分认为水传播影响种子库与地表植被的关系, 也 有研究表明高密度的淡水养殖致使沉水植物的盖度和生物量降低进而干扰沉水植物种子库的形成 ${ }^{[13,19,25]}$. 
这表明种子库与地表植被的关系除了随湿地地表植被类型的变化而变化外, 还存在着多种影响因素, 如不 同程度的人为干扰、环境因子 (水文、季风) 以及一些湿地恢复措施等等, 这些因素是相互影响和协同发展 的. 加强环境因子及人为干扰因素等对种子库与地表植被关系的研究对于湿地生态恢复及管理具有重要的 指导意义.

\section{2 湿地种子库植被恢复}

湿地生态系统是我国目前受威胁最严重的生境类型之一, 恢复和重建受损湿地生态系统的重要性越来 越被人们所认识, 并逐渐成为研究的热点. 作为湿地生态研究的重要组成部分, 湿地种子库在植被演替更新 和受损湿地恢复中起着十分重要的作用 ${ }^{[8]}$. 研究表明, 水生植物的种子在恶劣的环境中对种群的定居、维持 和重建都具有重要作用 ${ }^{[43]}$. Van der Valk 等在研究沼泽时指出, 沼泽在水位高时, 植被稀疏, 水位降低露出底 层后, 大量植被快速恢复, 这主要是由于大量的底泥种子库的存在 ${ }^{[6]}$. Leck 等在研究淡水沼泽时也发现种子 库密度和幼苗密度呈正相关 ${ }^{[4]}$. 王增茹等对塔里木河下游典型断面的种子库进行了实验室萌发和野外试验 的对比, 研究表明在野外进行萌发试验的结果更可靠 ${ }^{[45]}$, 这对利用种子库恢复退化湿地系统的植被提供了 参考.

种子库作为一种主要的植被恢复自然资源, 通过利用生态系统自身资源及特点自然地恢复湿地的植 被. 但是种子库在植被恢复与重建中的作用受多种因素的影响, 种子库种子萌发特征及种苗建群、种子库物 种组成、生境状况等都影响到其作用的发挥. Nishihiro 等发现在原有植被遭到破坏的情况下, 潜在的种子库 可以恢复受损湿地植被, 并可使一些在地表植被中已消失的种类得到恢复, 在利用种子库成功恢复日本 Kasumigaura 湖湿地植被的案例中, 认为微地形对于物种丰富的湖岸带植被恢复非常重要, 而种子库的来源则 影响恢复后植被的物种组成, 另外恢复区也容易受到外来物种人侵的影响, 在恢复初期对于外来物种的控 制对于恢复后的群落发展至关重要 ${ }^{[8]}$.

\section{1 湿地种子库幼苗萌发主要影响因素}

水文、水质条件影响着种苗萌发、营养供应、水胁迫、植物生长、分解和生产等湿地植被的生理、生态过 程. 水位变化与湿地植物的萌发密切相关, 从而通过影响植物种类而决定群落结构和演替格局. 营养物质通 过影响种苗的萌发和定居, 进而影响植物的生长和植物群落格局.

2.1 .1 水文 水文因素尤其是水位条件直接影响水生植物的萌发. Muencher 在 1936 年进行眼子菜属植物的 萌发实验时发现 $20 \sim 30 \mathrm{~cm}$ 水深更利于其萌发, 而在室外实验中则推荐设置 $30 \sim 60 \mathrm{~cm}$ 水深 ${ }^{[46]}$. Peterson 等 开展了淹水水位和底泥沉积对淡水潮汐湿地种子库种子萌发的影响, 研究结果表明淡水潮汐湿地的水位和 底泥沉积很大程度上影响着种子库种子的萌发, 进而影响了湿地植物的物种多样性 ${ }^{[47]}$. Nishihiro 等对日本 Kasumigaura 湖 25 种湖岸植物的萌发条件的研究发现, 低水位更有利于湖岸种子库中植物的萌发 ${ }^{[48]}$. 水文 条件是种子库种苗萌发的最主要影响因素, 而其他因素如氧气供应、温度和光照等往往是随水文条件的改 变而变化,进而间接影响着种子萌发过程、萌发率和种苗建群. 通过开展不同水文梯度下相关环境因子的变 化规律及其对种子库种苗萌发的影响研究具有十分重要的实践意义. 另外水位的波动、水流的状态等也影 响着种苗的定居, 相关研究还不多见.

2.1 .2 营养 湿地中 N、P 排放的增加导致不同生境类型的湿地植物群落结构和物种组成的变化, 这可能是 由于营养条件间接影响水生植物的萌发及建群所致. 水文条件也通过影响生物地球化学循环间接改变营养 元素的动态和供应, 如厌氧环境通过反硝化增加了氮的损失, 并通过释放底泥中的磷而增加磷的供应, 营养 的增加也可以促进浮游和底栖藻类的生长, 进而和幼苗的萌发及生长产生竞争甚至抑制. 有研究表明一些 水生植物的萌发表现出一定的营养限制, 如 N、P 会促进或抑制一些物种的萌发 ${ }^{[49]}$. Wills 等在 1995 年研究 了水文条件及营养物质对于水生植物种子库萌发和生物量的影响, 结果表明水文条件影响种苗的萌发, 而 氮的供给情况则控制水生植物的生物量 ${ }^{[50]}$. Johnson 在 2004 年对美国中部磷限制淡水湿地的种子库研究发 现, 磷的显著添加降低淹水条件下的种子库萌发率 ${ }^{[49]}$, 表明营养元素对种子萌发的影响往往与水文条件相 关,并且不同湿地种子库类型对营养物质的反应各异.

2.1 .3 物种 一些物种萌发需要特殊的条件, Van der Valk 等在 1978 年对草原湿地的研究中发现, 黑三棱属 
一些物种的种子萌发率至少在 5 年后随着种龄的增大而急剧增加; 而蔍草属一些物种的种子必须在低温状 态下在水中败藏一年以后再置于高温和强光下才能萌发 ${ }^{[6]}$. Nabity 等在对荷兰内陆盐沼湿地种子库植被恢 复效力的研究中发现, 盐度影响盐沼湿地植物的萌发和生长 ${ }^{[14]}$. 另外温度、光照、及氧供应等也影响湿地种 子库种苗的萌发, 有研究表明许多湿地物种能在 $5^{\circ} \mathrm{C}$ 条件下发芽, 大部分物种萌发不需要光照, 一些持久性 种子库的种子萌发需要光照, 有些则需要少量光照 ${ }^{[4]}$. 氧供应是影响萌发的另一重要因子, 研究显示大部分 物种可在有氧或氧含量较低的情况下萌发, 部分物种的萌发则要求缺氧条件 ${ }^{[44]}$. 种子库的萌发往往是多因 素影响的结果, 但在实际研究过程中很难兼顾所有物种的萌发条件, 而以目标种群或大多数物种的萌发为 主的萌发条件研究更具有实际意义.

种子库种苗萌发是种子库植被恢复的关键, 已有的研究表明水文因素及营养物质在一定程度上影响着 种子库种苗萌发, 目前水体污染是湿地退化的重要方面之一, 但还没有污染物对种子库种苗萌发的相关报 道. 通过对影响种苗萌发主要条件的研究有助于在种子库植被恢复实践中种苗萌发的适宜生境的创建提供 参考, 有必要加强这方面的研究.

\section{2 湿地种子库种苗建群适宜生境}

苗期是种群动力学的关键时期, 了解这一时期种苗对于生境条件的要求对于种群定居至关重要. 生长 早期的种苗存活主要受与淹水紧密相关的一些环境变量的影响, 种苗存活直至群落建成主要受光照以及与 淹水相关的因子的影响. Hölzel 等在对德国北部洪泛湿地植被恢复的研究中, 通过移除表土使基质的有机营 养和必需矿物质降低至目标群落的适应水平, 以创建适宜的种苗定居条件成功恢复目标群落 ${ }^{[51]}$. Takagawa 等对荇菜苗期建群安全生境的研究表明, 苗期的淹水时间、光照条件、波浪等对种苗的存活起着重要作用, 认为有必要通过适应管理来为种苗的存活创建适宜的生境, 以利用现有的种子库恢复荇菜群落 ${ }^{[52]}$. 由于水 体污染、水利控制工程建设以及河道管理措施等影响, 大量的湿地植被因生境条件的丧失而逐渐退化甚至 消失, 现有的植被恢复措施由于存在外来物种人侵、恢复后的植被类型单一等问题而备受质疑. 种子库在湿 地植被恢复中的优势越来越为人们所认识, 而种子库恢复初期种苗的定居和建群是恢复成功的关键, 适宜 的生境条件则是恢复成功的基础. 相关研究虽已有报道, 但多限于特定的植被或湿地类型. 尤其是我国湿地 类型多样、湿地退化程度及主要影响因素各异, 但相关研究极少, 开展湿地种子库种苗建群适宜生境的研究 不仅可为湿地种子库植被恢复工程奠定理论基础,也可为该领域的研究补充新的内容.

\section{3 湿地种子库植被恢复潜力}

由于种子比植物成株具有更强的耐胁迫能力, 更能逃避干扰、疾病和捕食的损害, 且具有随水文条件变 化而运动的特点, 因此种子库在植被遭受破坏后的自然恢复中常常起着关键作用. 在湿地保护和恢复实践 中充分利用原有湿地保留的种子库, 以及通过种子库移植等方法恢复湿地植被, 将更有利于湿地的物种多 样性和遗传多样性的恢复, 且具有效率高、费用低等特点. 在利用种子库进行受损湿地植被恢复的过程中, 通过研究种子库的规模、物种组成及物种丰富度等评估种子库的物种资源及植被恢复潜力至关重要, 这不 仅决定了能否利用种子库进行植被恢复, 同时对于恢复后的植被物种组成也起着重要作用. Blomqvist 等对 荷兰几条河流河岸种子库的研究发现, 由于种子库组成物种数较少, 且目标种极少, 因此并不适合用于恢复 河岸带植被 ${ }^{[53]}$. Matus 等通过对荷兰 Cirsio dissecti-Molinietum 沼泽湿地不同退化程度下湿地种子库物种组 成的分析以及对群落特征种种子寿命的评价, 有效评估了种子库对于恢复不同退化程度湿地的有效性, 并 对利用种子库恢复不同退化程度下的湿地植被提出相应的对策 ${ }^{[54]}$. Nabity 等对荷兰农业生态系统内盐沼湿 地种子库植被恢复效力的研究发现土地利用方式的改变威胁着盐沼湿地种子库物种组成,该类型土壤中没 有盐沼湿地指示种并且只有少量湿地物种, 在恢复过程中需引人盐沼湿地指示种 ${ }^{[14]} . \mathrm{Lu}$ 等研究了三峡库区 消涨带土壤种子库恢复消涨带植被的潜力, 认为种子库在三峡库区消涨带恢复建坝之前的植被尤其是木本 和多年生植物的可能性较低 ${ }^{[55]}$. 种子库的规模和物种数目是湿地种子库恢复潜力的物质基础, 而目标种的 存在与否则是恢复目标能否达成的关键. 通过对湿地种子库恢复潜力进行研究, 可以避免恢复的盲目性, 增 加目标种恢复成功的几率, 是湿地种子库植被恢复研究的重要部分. 另外, 不是在任何地方、任何生境均能 利用土壤种子库进行原有植被的自然恢复. 对于干扰严重、立地条件差、不利于种子定植、萌发和幼苗生长 的地段则需要结合人工重建和工程措施逐步达到植被恢复的目标. 


\section{4 湿地种子库植被恢复方法}

利用种子库恢复受损湿地植被一般有直接补充及利用基质中遗留的种子库和从临近植被生境相似区 域转移种子库两种方法, 其中后一种主要应用于原来植被完全消失的湿地植被恢复 ${ }^{[56]}$. 日本在利用土壤种 子库恢复水域及湿地植被中常用表土种子库喷播法、移植法以及种子库植被恢复与栽植法相结合的复合方 法等. 其中表土种子库喷播法对河流和自然湖泊的植被恢复效果很好 ${ }^{[8]}$. 利用种子库进行湿地植被恢复需 要明确所利用的种子库物种组成、种子库移植的最佳时间、种子库正常萌发与建群的适宜生境条件以及种 子库中非恢复物种的去除方法等问题, 以保证湿地植被恢复能够达到预期的效果. 另外, 种子库的采集深 度、湿地微生境对种子库的影响以及一些不可预料的结果等都是在利用种子库恢复湿地植被的实际工程中 需深人研究的内容.

\section{3 结论及展望}

湿地种子库在湿地植被恢复中的作用正日益受到重视, 对湿地种子库的研究为湿地植被的保护与恢复 提供了新的思路. 而保护和恢复湿地生物多样性, 植被恢复是先决条件. 作为植被恢复重建的材料和资源, 湿地种子库具有恢复该地域自然植被的潜力, 为植物群落的恢复或重建提供了可能 ${ }^{[3,57]}$.

目前在湿地种子库物种组成、时空分布及动态、种子库与地表植被之间的关系以及干扰对土壤种子库 的影响等的基础研究相对较多, 种子库在湿地植被恢复中的重要作用已经多有报道, 但是在利用种子库恢 复湿地植被方面多集中在萌发条件的研究, 并且研究的系统性和深度还有待提高, 种子库植被恢复工程技 术及应用研究报道相对较少. 我国在湿地种子库方面的研究由于起步较晚, 因此还存在一些不足之处, 今后 应加强以下几个方面的研究:

1) 目前国内对于天然湖泊、水库等湿地的种子库研究相对较多, 但对于一些典型的区域如城市河流湖 泊湿地、逆境环境尤其是受污染水体等湿地种子库的研究仍属空白, 对于其种子库的规模、物种组成及多样 性、空间分布格局等均无相关报道, 因此展开这些区域的土壤种子库研究, 有助于整体把握湿地种子库特 性,并对强烈的人为干扰下退化湿地的植被恢复策略提供指导.

2) 种子的萌发和生长受环境光照、氧含量、水文、营养盐、污染物等因素的影响, 目前关于水位深度、营养 物质等对于萌发的影响研究较多, 但种子的萌发一般是多因素影响的结果, 尤其是在植被恢复实践过程中很 难将环境条件控制为单因子, 水质条件 (如污水) 及水文因素往往是影响种子萌发的关键, 但目前研究多限于 少数影响因素的研究, 并且同一影响因素不同变化梯度对种子萌发的影响研究相对较少. 水污染导致的湿地 退化是目前湿地恢复面临的主要问题之一, 因此有必要针对目前水污染严重的问题开展不同污染水平的污水 对湿地种子库萌发影响的研究. 研究种子库萌发与环境因子之间的相互关系, 有助于准确评估湿地种子库在 植被恢复中的作用与潜力, 定位所需环境边界条件,为湿地种子库植被恢复实践奠定理论基础.

3) 目前国内对于湿地种子库的研究多停留在理论研究阶段, 对于种子库植被恢复的应用研究也仅见于 对湿地种子库植被恢复潜力的评估方面, 而对于湿地种子库植被恢复实践尤其是种子库的采集及移植方 式、种子库萌发和幼苗建群的适宜生境以及植被恢复过程中的管理方法等研究还未见报道, 加强这方面的 研究可为湿地的植被恢复和保护提供切实可行的解决方案.

4) 人为干扰及环境因子, 如人为因素导致的水文变化、岸带建设、土地利用转换、水体污染等不仅影响 着湿地种子库的规模、物种组成及时空分布等, 对于种子库的植被恢复潜力也起着重要作用. 加强湿地种子 库与环境之间关系的研究不仅有助于湿地物种多样性保护, 同时对于利用种子库恢复受损湿地植被也有一 定的指导意义. 鉴于当前湿地退化加剧的现状和湿地保护的需要, 开展这方面的研究不但对湿地保护管理 具有重要的现实意义,也将成为今后湿地生态研究的重点之一.

\section{4 参考文献}

[ 1 ] 周 进, Hisako TI, 李 伟等. 受损湿地植被的恢复与重建研究进展. 植物生态学报, 2001,25(5):561-572.

[ 2 ] Cavers PB. Seed banks-memory in soil. Canadian Journal of Soil Science, 1995, 75 (1):11-13.

[ 3 ] Goodson JM, Gurnell AM, Angold PG et al. Riparian seed banks: structure, process and implications for riparian management. Progress in Physical Geography, 2001, 25 (3):301-325. 
[4] 李 伟,刘贵华,周 进等. 淡水湿地种子库研究综述. 生态学报,2002,22:395-402.

[ 5 ] Van der Valk AG, Davis CB. The seed banks of prairie glacial marshes. Canadian Journal of Botany, 1976, 54: 1832-1838.

[ 6 ] Van der Valk AG, Davis CB. The role of seed banks in the vegetation dynamics of prairie glacial marshes. Ecology, 1978, $\mathbf{5 9}: 322-335$.

[ 7 ] Wetzel PR, Van der Valk AG, Toth LA. Restoration of wetland vegetation on the Kissirnrnee river flood plain: Potential role of seed banks. Wetlands, 2001, 21(2):189-198.

[ 8 ] Nishihiro J, Nishihiro MA, Washitani I. Restoration of wetland vegetation using soil seed banks: lessons from a project in Lake Kasumigaura, Japan. Landscape Ecol Eng, 2006, 2 :171-176.

[ 9 ] Li EH, Liu GH, Li W et al. The seed-bank of a lakeshore wetland in Lake Honghu: implications for restoration. Plant Ecol, $2008,195: 69-76$.

[10］刘贵华,李 伟,王相否等. 湖南茶陵湖里沼泽种子库与地表植被的关系. 生态学报,2004,24:450-456.

[11] 叶 春, 刘 杰, 于海婵等. 东太湖 3 种沉水植物群落区底泥种子库与幼苗库. 生态环境, 2008,17:1091-1095.

[12] Liu GH, Li W, Zhou J et al. How does the propagule bank contribute to cyclic vegetation change in lakeshore marsh with seasonal drawdown. Aquatic Botany, 2006, 84:137-143.

[13 ] Xiao C, Dou WF, Liu GH. Variation in vegetation and seed banks of freshwater lakes with contrasting intensity of aquaculture along Yangtze River, China. Aquatic Botany, 2010, 92:195-199.

[14] Nabity PD, Hoagland KD. Seed bank viability of Inland saline wetland sites in agro-ecosystems. Great Plains Research, 2006,16 (2):173-180.

[15] 刘贵华,萧 葴,陈漱飞等. 土壤种子库在长江中下游湿地恢复与生物多样性保护中的作用. 自然科学进展, 2007, 17 (6):741-747.

[16] 彭少麟, 陈蕾伊, 侯玉平等. 恢复与重建自然与文化的和谐一2011 生态恢复学会国际会议简介. 生态学报, 2011, 31 (17) :5105-5106.

[17] Poiani KA, Johnson WC. Effect of hydro-period on seed bank composition in semi-permanent prairie wetlands. Canadian Journal of Botany, 1989, $67: 856-864$.

[18］李洪远,莫训强,郝 翠. 近 30 年来土壤种子库研究的回顾与展望. 生态环境学报,2009,18(2):731-737.

[19] 萧 荗, 刘文治, 刘贵华. 丹江口库区滩涂与人库支流植被与土壤种子库: 水传播潜力探讨. 植物生态学报, 2011, 35 (3) $: 245-255$.

[20] Griffith AB, Forseth IN. Primary and secondary seed dispersal of a rare, tidal wetland annual, Aeschynomene virginica. Wetlands, 2002 , 22 :696-704.

[21] Merritt DM, Wohl EE. Plant dispersal along rivers fragmented by dams. River Research and Applications, 2006, 22 :1-26.

[22] Cherry JA, Gough L. Temporary floating island formation maintains wetland plant species richness: The role of the seed bank. Aquatic Botany, 2006, $85: 29-36$.

[23] Espinar JL, Clemente L. The impact of vertic soil cracks on submerged macrophyte diaspore bank depth distribution in Mediterranean temporary wetlands. Aquatic Botany, 2007, 87:325-328.

[24] Liu GH, Zhou J, Li W et al. The seed bank in a subtropical freshwater marsh: Implications for wetland restoration. Aquatic Botany, 2005, 81:1-11.

[25] Yuan LY, Liu GH, Li W et al. Seed bank variation along a water depth gradient in a subtropical lakeshore marsh, Longgan Lake, China. Plant Ecology, 2007, 189:127-137.

[26] Willson SD, Moore DRJ, Keddy PA. Relationships of marsh seed banks to vegetation patterns along environmental gradients. Freshwater Biology, 1993, 29:361-370.

[27] McGraw JB. Seed bank properties of an Appalachian sphagnum bog and a model of depth distribution of viable seeds. Canadian Journal of Botany, 1987, 65 :2028-2035.

[28] Bonis A, Grillas P. Deposition, germination and spatiotemporal patterns of charophyte propagule banks: A review. Aquatic Botany, 2002, $72: 235-247$.

[29] Welling CH, Pederson RL, Van der Valk AG. Temporal patterns in recruitment from the seed bank during drawdowns in a prairie wetland. Journal of Applied Ecology, 1988, 25 :999-1007.

[30] Nilsson C, Gardfjell M, Grelsson G. Importance of hydrochory in structuring plant communities along rivers. Canadian Journal of Botany, 1991, $69: 2631-2633$.

[31] Jutila HM. Germination in Baltic coastal wetland meadows: Similarities and differences between vegetation and seed bank. 
Plant Ecol, 2003, 166:275-293.

[32] 刘贵华,刘幼平,李 伟. 淡水湿地种子库的小尺度空间格局. 生态学报,2006,26(8):2739-2743.

[33] Cockel CP, Gurnell AM. An investigation of the composition of the urban riparian soil propagule bank along the River Brent, Greater London, UK, in comparison with previous propagule bank studies in rural areas. Urban Ecosyst, 2012,15 (2) :367-387.

[34 ] Hölzel N, Otte A. The impact of flooding regime on the soil seed bank of flood-meadows. J Veg Sci, 2001, 12:209-218.

[35] Brown RL, Chenoweth J. The effect of Glines Canyon Dam on hydrochorous seed dispersal in the Elwha River. Northwest Sci, 2008, 82 ( sp1) : 197-209.

[36] Liu WZ, Zhang QF, Liu GH. Seed bank of a river-reservoir wetland system and their implications for vegetation development. Aquatic Botany, 2009, 90:7-12.

[37] Capon SJ. Effects of flooding on seedling emergence from the soil seed bank of a large desert floodplain. Wetlands, 2007, 27 :904-914.

[38 ] Baldwin AH, Egnotovich MS, Clerke E. Hydrologic change and vegetation of tidal freshwater marshes: Field, greenhouse and seed bank experiments. Wetlands, 2001, $21: 519-531$.

[39] 李守淳,刘文治,刘 晖等. 蚌湖湖滨带的土壤种子库特征. 植物科学学报,2011,29(2):164-170.

[40] Van der Valk AG. Succession in wetlands: A Gleasonian approach. Ecology, 1981, 62 (3) :688-696.

[41] Chang ER, Jefferies RL, Carleton TJ. Relationship between vegetation and soil seed banks in an arctic coastal marsh. Journal of Ecology, 2001, 89:367-384.

[42] Smith LM, Kadlec JA. Seed banks and their role during drawdown of a North American marsh. Journal of Applied Ecology, 1983, $20: 673-684$.

[43 ] Lokker C, Lovett-Doust L, Lovett-Doust J et al. Seed output and the seed bank in Vallisneria americana (Hydroeharitaceae). American Journal of Botany, 1997, 84 (10):1420-1428.

[44] Leck MA, Simpson RL. Tidal freshwater wetland zonation: seed and seedling dynamics. Aquatic Botany, 1994 , 47: 61 75.

[45] 王增茹,徐海量, 尹林克等. 土壤种子库萌发实验在野外与室内的对比分析. 中国沙漠,2009,29(2):264-269.

[46] Muenscher WC. The germination of seeds of Potamogeton. Annals of Botany, 1936, 50: 805-822.

[47] Peterson JE, Baldwin AH. Seedling emergence from seed banks of tidal freshwater wetlands: response to inundation and sedimentation. Aquatic Botany, 2004, 78:243-254.

[48 ] Nishihiro J, Araki S, Fujiwara N et al. Germination characteristics of lakeshore plants under an artificially stabilized water regime. Aquatic Botany, 2004, 79(4) :333-343.

[49] Johnson S. Effects of water level and phosphorus enrichment on seedling emergence from marsh seed banks collected from north Belize. Aquatic Botany, 2004, 79:311-323.

[50] Willis C, Mitsch WJ. Effects of hydrology and nutrients on seedling emergence and biomass of aquatic macrophytes from natural and artificial seed banks. Ecological Engineering, 1995, 4:65-76.

[51] Hölzel N, Otte A. Restoration of a species-rich flood meadow by topsoil removal and diaspore transfer with plant material. Appl Veg Sci, 2003, 6(2):131-140.

[52] Takagawa S, Nishihiro J, Washitani I. Safe sites for establishment of Nymphoides peltata seedlings for recovering the population from the soil seed bank. Ecol Res, 2005, 20:661-667.

[53] Blomqvist MM, Bekker RM, Vos P. Restoration of ditch bank plant species richness: the potential of the soil seed bank. Appl Veg Sci, 2003, 6(2):179-188.

[54] Matus G, Verhagen R, Bekker RM et al. Restoration of the Cirsio dissecti-Molinietum in The Netherlands : can we rely on soil seed banks? Appl Veg Sci, 2003, 6 ( 1 ) : 73-84.

[55] Lu ZJ, Li LF, Jiang MX et al. Can the soil seed bank contribute to re-vegetation of the drawdown zone in the Three Gorges Reservoir Region. Plant Ecol, 2010, 209 :153-165.

[56] Van der Valk AG, Pederson RL, Davis CB. Restoration and creation of freshwater wetlands using seed banks. Wetlands Ecology and Management, 2004,1 ( 4 ) : 191-197.

[57］侯志勇,谢永宏,于晓英等. 淡水湿地种子库的研究方法、内容与展望. 生态学杂志,2008,27(8):1400-1405. 